\title{
Palavras do Editor
}

A revista Antíteses, criada em 2007 completa com esse volume oito anos de atividade ininterrupta e regular. Foram 17 edições entre números regulares e números especiais. Das 827 submissões realizadas no período foram aceitas e publicadas 447 nas diversas seções da revista. No seu primeiro ano de funcionamento, contava com 510 usuários ( leitores, avaliadores, autores) cadastrados. Hoje, esse número, atíngiu 1892.

Já é, portanto, uma história de sucesso construída com o auxílio de muitas pessoas e instituições. Autores, avaliadores, editores, bibliotecários, programadores e agências de financiamento.

A conjuntura atual, no Brasil, no campo da edição de periódicos científicos transparece a normatização e pressão das agências de fomento e avaliação dos programas de posgraduação. Um dos aspectos mais importantes nas avaliações dos programas de posgraduação é precisamente a publicação por parte dos docentes e discentes em períodicos 'ranqueados' pelas próprias agências. Assim, as revistas científicas precisam estar bem qualificadas no 'ranking' para poderem receber apoio e, ao mesmo tempo, serem escolhidas pelos autores.

Mas para manter a 'nota' no sistema 'qualis CAPES', os periódicos necessitam de cumprir uma série de requisitos, entre eles, manter o processo de avaliação por pares; conselho consultivo e editorial atuante, não endogenia na origem dos artigos, etc. Além disso, existe, também uma pressão mais geral, para a internacionalização da 'ciência brasileira', o que significa a internacionalização dos períódicos científicos referenciados. Essa internacionalização refere-se a quantidade de publicação oriunda de outros paises, bem como a necessária participação de avaliadores estrangeiros.

A revista Antiteses, desde seu início, tem sido atuante nesse sentido, o que pode ser constatado na significativa presença de autores no âmbito da América do Sul e demais paises. Porém, a internacionalização, representa necessariamente um aumento de trabalho e de recursos financeiros necessários. O trabalho de edição é pouco reconhecido e valorizado, quer seja internamente às instituições, nas quais raramente existe oficialmente a figura do 'editor de periódicos científicos' e, externamente, quer seja pelas próprias agências de avaliação. Os recursos financeiros, por sua vez, cada vez mais escassos e restritos aos níveis superiores do 'qualis'.

Então acontecem alguns paradoxos: é necessário publicar, mas o trabalho para manter um períodico cientifico não é valorizado ou reconhecido. Por sua vez, os autores preciam publicar, mas 
os editores enfrentam sérias dificuldades em encontrar avaliadores externos disponíveis para garantir a qualidade e os padrões exigidos. Interessante, pois os avaliadores são, também, os autores. Ainda, por último, os requisitos necessários para a avaliação dos periódicos pela CAPES, exigem recursos financeiros para edição, tradução, normalização, etc, mas não existem recursos, ou são extremamente escassos.

Entretanto, apesar dessa avaliação, um tanto pessimista, os membros do Programa de Pósgraduação em História Social, e o Departamento de História, da Universidade Estadual de Londrina, têm mantido o compromisso de continuar a publicação da revista Antíteses. A publicação, nesse número, do dossiê 'Identidades cristãs no mundo romano', organizado pela Professora Mônica Selvatici confirma a decisão de ter a revista como uma das atividades centrais do programa de pósgraduação.

Desejamos a todos uma boa leitura de mais um número da revista ANTÍTESES

Gilmar Arruda - editor. 